\title{
Main properties of steviol glycosides and their potential in the food industry: a review
}

\author{
Cesar GonzÁlez ${ }^{1 *}$, María TAPIA $^{2}$, Elevina Pérez ${ }^{2}$, Dominique PALleT $^{3}$, Manuel DornieR $^{4}$
}

${ }^{1}$ Programa Ing. Agroind., Decanato Agron.,

Univ. Centroccident. "Lisandro Alvarado", Av. Florencio Jiménez, Barquisimeto 3001, Venezuela, cesargonzalez@ucla.edu.ve

2 Inst. Cienc. Tecnol. Aliment., Fac. Cienc., Univ. Cent. Venezuela, Calle Suapure, Lomas de Bello Monte, Caracas 1050, Venezuela

${ }^{3}$ CIRAD, UMR 95 QualiSud, TA B-95/16,

F-34398 Montpellier cedex 5, France

${ }^{4}$ Montpellier SupAgro, UMR 95 QualiSud, BP 5098, F-34093 Montpellier cedex 5, France

${ }^{*}$ Correspondence and reprints

Received 7 July 2013 Accepted 10 September 2013

Fruits, 2014, vol. 69, p. 127-141 (C) 2014 Cirad/EDP Sciences All rights reserved DOI: 10.1051/fruits/2014003 www.fruits-journal.org

RESUMEN ESPAÑOL, p. 141

\section{Main properties of steviol glycosides and their potential in the food industry: a review.}

Abstract - Introduction. In recent decades, there has been increased interest in developing natural non-caloric sweeteners, providing sensory properties similar to sucrose. One of the most promising alternatives is the steviol glycosides, high-sweetness compounds extracted from the leaves of Stevia rebaudiana Bertoni. Characteristics and properties. In this review article, the characteristics of this plant are described. According to the relevant literature data, this review provides insight into the major steviol glycosides as well as their main characteristics and properties. Toxicity and legislation. We describe the current situation on the toxicity and the legal framework of the above sweeteners. Extraction techniques. This review describes the techniques developed for extraction and purification, including conventional extraction with water/solvent, ion exchange, enzymatic extraction, supercritical fluid and with a focus on membrane filtration, for its proven advantages in the purification of aqueous extract obtained by leaching of the leaves. Applications. This review also presents various evidence relating to the implementation of steviol glycosides in the food industry, with an emphasis on their use in the formulation of fruit juices. Conclusions. Finally, the future prospects of these natural sweeteners are presented. They highlight the need for research in this area, and the great appeal and commercial potential of such compounds, which should be focused on continuous assessment in relation to issues such as the intensity, persistence of sweetness and the absence of other residual flavors, in order to ensure their acceptance, preference and choice by the general public.

Stevia rebaudiana / leaves / extraction / glycosides / sweeteners / stevioside / food industry / fruit juices

Synthèse sur les principales caractéristiques des glycosides de stéviol et leur intérêt dans l'industrie alimentaire.

Résumé - Introduction. Au cours des dernières décennies, il est apparu un intérêt croissant pour le développement des édulcorants naturels, non-caloriques, offrant des propriétés sensorielles similaires à celles du saccharose. Parmi les produits les plus prometteurs apparaissent les glycosides de stéviol, composés très édulcorants extraits des feuilles de Stevia rebaudiana Bertoni. Caractéristiques et propriétés. Dans cette synthèse, nous décrivons les caractéristiques de S. rebaudiana. À partir des données de la littérature, cette étude donne un aperçu des principaux glycosides de stéviol et de leurs principales caractéristiques et propriétés ; elle souligne d'autres qualités de ces produits. Toxicité et législation. Nous faisons un point sur la toxicité et le cadre juridique des édulcorants concernés. Techniques d'extraction. Notre synthèse décrit les techniques mises au point pour l'extraction et la purification, y compris l'extraction conventionnelle avec de l'eau ou solvant, l'échange d'ions, l'extraction enzymatique et le fluide supercritique ; elle met l'accent sur la filtration membranaire du fait de ses avantages prouvés dans la purification de l'extrait aqueux obtenu par lixiviation des feuilles de Stevia. Applications. Notre synthèse présente également divers éléments relatifs à la mise en œuvre des glycosides de stéviol dans l'industrie alimentaire, en insistant sur leur utilisation dans l'élaboration de jus de fruits. Conclusions. Enfin, basées sur le jugement des auteurs, les perspectives d'avenir de ces édulcorants naturels sont présentées. Elles soulignent le besoin de recherches dans ce domaine, le grand attrait et le potentiel commercial de ces composés. Des recherches devraient être axées sur l'évaluation de caractéristiques telles que l'intensité et la persistance du goût édulcorant, ainsi que l'absence d'autres saveurs résiduelles, aptes à assurer l'acceptation de ces produits, leur préférence et leur choix par le grand public.

Stevia rebaudiana / feuille / extraction / glycoside / édulcorant / stévioside / industrie alimentaire / jus de fruits 


\section{Introduction}

Currently, the sweeteners used in the formulation of low-calorie foods, such as acesulfame-K, aspartame, neotame, saccharin and sucralose, are high-intensity synthetic compounds. As well as being innutritious, many of these sweeteners have been shown to be carcinogenic and are associated with various other diseases [1]. For this reason the food industry, in recent years, has dedicated considerable effort to the development of alternative sweetening agents with similar characteristics and properties, but obtained from natural sources. One of the most important features that have been sought in these natural alternatives is the similarity of their sensory profile to that of sucrose and other ingredients, in order to provide a highquality product which also generates a wide sensory acceptance [2].

A small number of low-calorie natural compounds, such as, for example, thaumatin, glycyrrhizin, xylitol, phyllodulcin, mogroside and stevioside, are now used commercially in several products [3]. Of these, the compounds obtained from Stevia rebaudiana, principally stevioside and rebaudioside $\mathrm{A}$, have, in the last decade, generated considerable interest, due to their high solubility in water, intense sweetness and synergistic effects with other sweeteners Stevioside and rebaudioside A are extracted from the leaves of $S$. rebaudiana Bertoni; they are available commercially in Japan, Korea, China, South-East Asia and South America, where they have been used for several decades to sweeten a variety of foods, including drinks, sweet vegetables, pickles and seafood [4].

On the other hand, and particularly in beverages and fruit juices, the sensory properties and organoleptic attributes of the final product are influenced by several factors such as the type and quantity of acids and other added sweeteners. In the present review, we describe the latest developments that have taken place as regards the properties, some extraction techniques and analysis of the steviol glycosides present in the leaves of $S$. rebaudiana. We then discuss, with specific examples, their application in the formulation of foods based on fruits.

\section{Main characteristics of steviol glycosides}

Stevia rebaudiana Bertoni is a herbaceous plant in the Asteraceae (Compositae), native to Paraguay, and mainly found in certain regions of South America [5].

The commercial exploitation of Stevia has risen significantly since the 1970 s, when several Japanese researchers developed a series of protocols for the extraction and refining of the sweetener compounds, diterpene glycosides, found in its leaves [6]. More than 30 of these compounds have been reported to date [7, 8]; among them, the best known molecules are stevioside and rebaudioside A (figure 1, table I). Stevioside is normally found in greater quantities than the other compounds, between $4 \%$ and 20\% weight of the dried leaves, and it is known that it is about 300 times sweeter than sucrose [5]. Stevia sweetness mainly depends on the genetic characteristics (variety), although several successful crop agronomic improvements have recently been implemented to raise the proportion of rebaudioside A; the variety Morita II has gained more relevance, presenting this quality [5].

As a result of the dominance of stevioside, the crude extracts obtained from the leaching of Stevia leaves have a characteristic bitter aftertaste [6]. Nevertheless, extracts with higher proportions of rebaudioside A have a much improved flavor profile, due to their physico-chemical and organoleptic characteristics. Rebaudioside A is also highly soluble in water, thus facilitating its use in food elaboration [6].

Stevioside and rebaudioside A have multiple advantages as dietary supplements. They are non-metabolizable (non-caloric), non-fermentable and do not cause dental caries. Another notable benefit is that the consumption of both steviol glycosides is safe for human health and there are no restrictions on their use by people suffering from diabetes [9, 10]. Stevioside and rebaudioside A represent the few natural sweeteners that are non-caloric, ready-made in nature and that can be reliably produced at an industrial level. In fact, high doses of stevioside (750-1500 mg per day) have been 


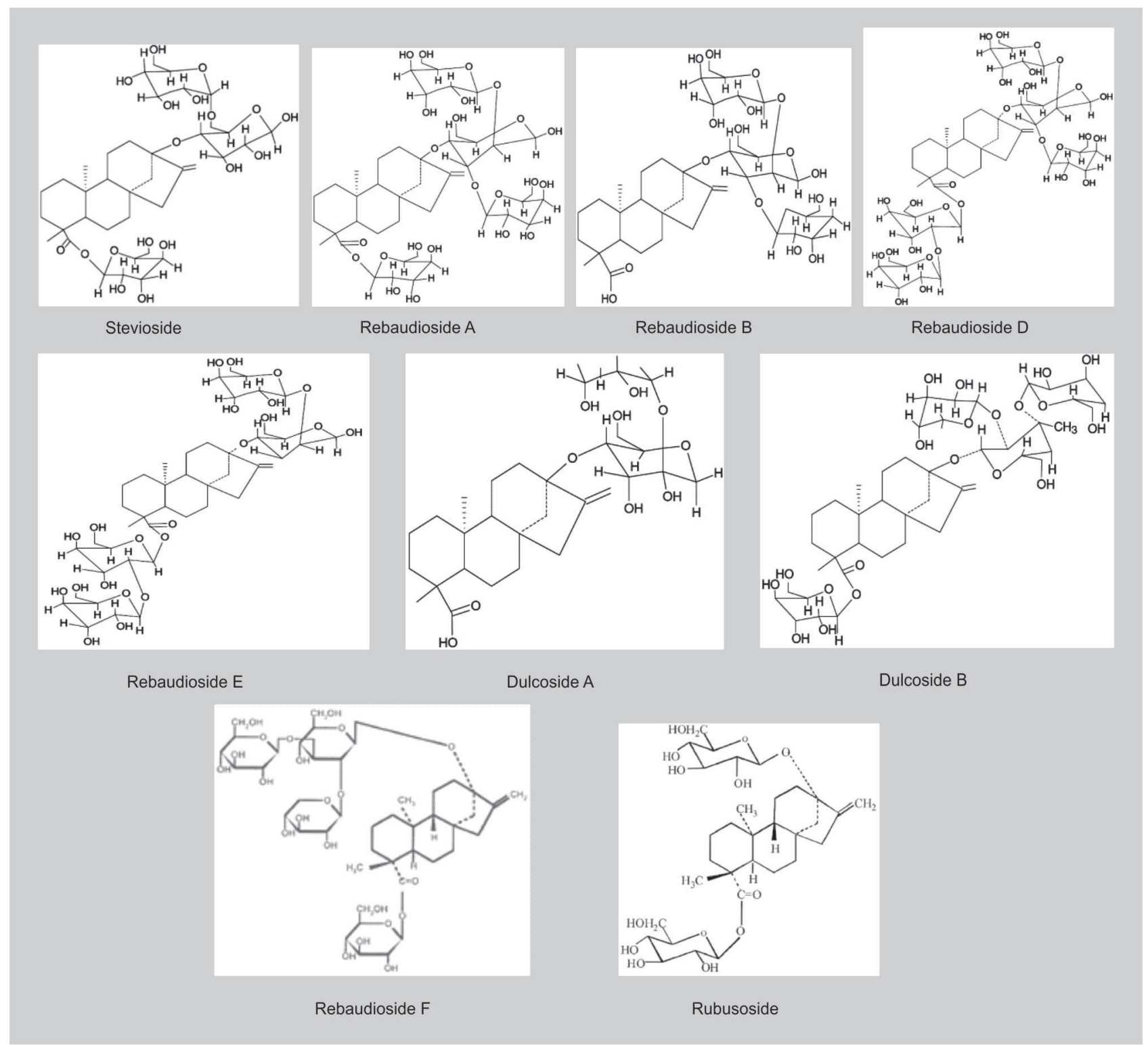

used with favorable results for the treatment of hypertension and type 2 diabetes [13, 14].

The therapeutic value of stevioside consists of the fact that it substitutes sugar whilst at the same time stimulating the secretion of insulin in the pancreas during the treatment of diabetes and other carbohydrate metabolism disorders [9, 15].

Thus, obese people are able to lose weight, thanks to the fact that they can continue to eat sweet foods whilst lowering their sugar intake [16]. In addition, steviol glycosides have been shown to participate in the reduction of blood cholesterol [16] and improve cell regeneration and blood clotting, as well as suppressing neoplastic growth and strengthening blood vessels $[17,18]$.

Stevioside and rebaudioside A also exhibit anti-inflammatory and diuretic properties [19], prevent ulceration of the gastrointestinal tract $[18,20]$ and show antihyperglycemic [21-23], anti-hypertensive,
Figure 1.

Chemical structure of major glycosides found in Stevia rebaudiana Bertoni $[3,42]$. 


\section{González et al.}

Table I.

Glycosides found in Stevia rebaudiana leaves [8, 11, 12].

$\begin{array}{lcccc}\text { Glycoside } & \begin{array}{c}\text { Molecular } \\ \text { formula }\end{array} & \begin{array}{c}\text { Sweetening power } \\ \text { (with reference to saccharose) }\end{array} & \begin{array}{c}\text { Concentration in leaf } \\ \text { (\% w/w) }\end{array} & \begin{array}{c}\text { Proportion of glycoside in the leaves } \\ \text { (\% of total steviol glycosides) }\end{array} \\ \text { Stevioside } & \mathrm{C}_{38} \mathrm{H}_{60} \mathrm{O}_{18} & 150-300 & 4-14 & 43.1-79.6 \\ \text { Rebaudioside A } & \mathrm{C}_{44} \mathrm{H}_{70} \mathrm{O}_{23} & 250-450 & 2-4 & 1.6-9.9 \\ \text { Rebaudioside } \mathrm{C} & \mathrm{C}_{44} \mathrm{H}_{70} \mathrm{O}_{22} & 120-500 & 1-2 & 0.5-6.0 \\ \text { Steviolbioside } & \mathrm{C}_{32} \mathrm{H}_{50} \mathrm{O}_{13} & 100-125 & <0.4 & 0.3-3 \\ \text { Rubusoside } & \mathrm{C}_{32} \mathrm{H}_{50} \mathrm{O}_{13} & 100-120 & <0.4 & \text { Undefined } \\ \text { Rebaudioside B } & \mathrm{C}_{38} \mathrm{H}_{60} \mathrm{O}_{18} & 300-350 & <0.4 & 0-0.02 \\ \text { Rebaudioside D } & \mathrm{C}_{50} \mathrm{H}_{80} \mathrm{O}_{28} & 250-450 & <0.4 & 0-0.4 \\ \text { Rebaudioside E } & \mathrm{C}_{44} \mathrm{H}_{70} \mathrm{O}_{23} & 150-300 & <0.4 & 5.5-43.2 \\ \text { Rebaudioside F } & \mathrm{C}_{43} \mathrm{H}_{68} \mathrm{O}_{22} & \text { Undefined } & <0.4 & 0.04-0.1 \\ \text { Dulcoside A } & \mathrm{C}_{38} \mathrm{H}_{60} \mathrm{O}_{17} & 50-120 & 0.4-0.7 & 0.2-0.4\end{array}$

anti-tumor, anti-diarrheal and immunomodulatory activities [24]. The above-mentioned beneficial effects of steviol glycosides prove that they could be useful not only as natural sweeteners, but also as agents of preventive chemotherapy [15]. Recently, further properties of Stevia leaf extracts have been reported, including antibacterial, antiamnesic and antiviral activities. They have also been shown to have positive therapeutic effects in the treatment of neuralgia, anemia, lumbago, rheumatism, eczema and dermatitis [25].

\section{Toxicity and legislation}

One of the strongest arguments for the safety of Stevia for human health is that there have been no reported adverse effects over more than hundreds of years of continuous use by Paraguayans [3]. A comprehensive examination of the toxicity of stevioside and related compounds, emphasizing their therapeutic benefits, has been reviewed [26-28]. In addition, safety assessments of stevioside and the corresponding clinical trials have been well documented in a recent article [28]. These and other reports show that daily oral consumption at a reasonable level of stevioside ( $5 \mathrm{mg} \cdot \mathrm{kg}^{-1}$ of body weight) is safe and is also guaranteed to be neither carcinogenic nor mutagenic [15].
All these studies provide clear evidence that the extracts obtained from Stevia leaves can be safely used by both healthy people and diabetics, as well as providing an important source of antioxidants in the human diet [15].

With regard to finished product marketing regulations drawn up for Stevia-based sweeteners in the United States, in recent years the Food and Drug Administration (FDA) has granted the respective permissions for their use in food to companies such as Cargill and Merisant. In Europe, Switzerland, as well as a large number of countries, currently allows the use of Stevia sweeteners in foods and beverages, but the procedure required for the commercialization and approval of the finished products is cumbersome. On the other hand, France approved Stevia-based products in 2010 [3].

\section{Stability of steviol glycosides}

Several investigations have demonstrated the stability of stevioside and rebaudioside A under room temperature, neutral $\mathrm{pH}$ and sunlight conditions. These sweeteners can be used under $\mathrm{pH}$ conditions ranging from 2 to 10 and at temperatures of up to $120{ }^{\circ} \mathrm{C}$ [29-34].

The stability of a stevioside-based sweetener in solutions formulated with different 
organic acids (citric, tartaric and phosphoric acid) and vitamins (thiamine, riboflavin, niacin and pyridoxine) under different storage conditions was evaluated [29]. Its application as a sweetener in coffee and tea was also assessed. The stevioside showed stability when incubated at a high temperature $\left(120^{\circ} \mathrm{C}\right)$ for one hour, although it degraded at temperatures above $140{ }^{\circ} \mathrm{C}$ [30]. An aqueous solution of the stevioside remained stable over a $\mathrm{pH}$ range of 2 to 10 at $80^{\circ} \mathrm{C}$. Stevioside content did not exhibit significant changes when incubated for up to $4 \mathrm{~h}$ with water-soluble vitamins at $80^{\circ} \mathrm{C}$. When subjected to extremely acid conditions ( $\mathrm{pH} 1)$, however, a significant decrease in stevioside concentration was observed. As expected, the authors found that ascorbic acid had a protective effect against the degradation of the stevioside. No interaction at room temperature was found after 4 months of incubation of the aqueous media. Studies on the stability of the stevioside in organic acid solutions showed a tendency to greater decomposition of the sweetener at low $\mathrm{pH}$, depending on the acid media.

Moreover, the stability of steviol glycosides in diverse food products [semiskimmed milk, soy drinks, fermented milk drinks, ice cream, yogurt (made with both full cream and skimmed milk), dry biscuits and jam] was assessed [31]. Storage conditions were those recommended for each type of food $\left(-18^{\circ} \mathrm{C}\right.$ for ice cream, $6^{\circ} \mathrm{C}$ for yogurt and $20^{\circ} \mathrm{C}$ for skimmed and fermented milk). Stevioside recovery was between $96 \%$ and $103 \%$, thus demonstrating that the steviol glycosides had not decomposed in any of the samples tested.

Meanwhile, Praskash et al. evaluated the stability of stevioside and rebaudioside A and the possible formation of steviol aglycone in different soft drinks [32]. Samples made with these sweeteners were stored for (24, 48 and 72) h at $80^{\circ} \mathrm{C}$ before analysis. The steviosides degraded by over $70 \%$, with rebaudioside A showing greater stability than stevioside. The highest level of degradation (71\%) was observed in lemonade with caffeine after $72 \mathrm{~h}$, while the energy drink degraded by just $27 \%$ (the value referred to degradation of stevioside). They also reported, as for previous publications
[33], that the in vitro synthesis of stevioside and rebaudioside $\mathrm{A}$, after incubation with human microflora under strict anaerobic conditions, produced a degradation of stevioside to steviol after $10 \mathrm{~h}$, whereas rebaudioside A was completely degraded after $24 \mathrm{~h}$. In vitro tests with rat intestinal microflora showed a complete degradation of stevioside in 2 days, while that of rebaudioside A required 6 days.

Finally, the stability of rebaudioside A in solutions at a pH range of 2.8-4.2 (simulating normal conditions of commercial beverages) was studied [34]. Specifically, solutions with a $\mathrm{pH}$ between 2.8 and 3.2 were used to simulate lemon-lime-flavored drinks, solutions with a $\mathrm{pH}$ of 3.8 for soft drinks and $\mathrm{pH} 4.2$ for root beer. Samples were stored at different temperatures [ $[5,20$, 30 , and 40$)^{\circ} \mathrm{C}$ for 26 weeks. The results indicated that 7 to 12 minor degradation products were obtained from rebaudioside A without appreciable loss of sweetness. The stability of rebaudioside A, which depends on $\mathrm{pH}$, temperature and storage time, was also studied. The degree of degradation increases with lower $\mathrm{pH}$, and higher temperature and storage time.

\section{Techniques for the extraction and purification of steviol glycosides}

Several studies have focused on the evaluation of different methods and techniques for the extraction of steviol glycosides from Stevia leaves.

The most used is the conventional extraction method (extraction medium: hot water) [5] where powdered Stevia leaves were mixed with hot distilled water [ $78 \pm$ 1) $\left.{ }^{\circ} \mathrm{C}\right]$ at a $1: 14(\mathrm{~g}: \mathrm{mL})$ ratio in a water bath for $56 \mathrm{~min}$. The aqueous extract was then cooled to room temperature and filtered before centrifuging at an agitation speed of $5334 \mathrm{~g}$ for $26 \mathrm{~min}$ in order to obtain a primary clarification of the extract. This research also evaluated the use of fresh Stevia leaves for the preparation of aqueous Stevia solution at a concentration of $10 \%$. The sweeteners from dry Stevia leaves were 
extracted in cold water for $2 \mathrm{~h}$. The solids were then separated from the solution by vacuum filtration [5].

Similarly, Vanneste et al. used cold water as a solvent to avoid extracting larger impurities which are dragged along by heat and are then much more difficult to remove using membranes [13]. A solution of $20 \mathrm{~g}$ of leaves per liter of water was prepared and shaken for $2 \mathrm{~h}$ at $5^{\circ} \mathrm{C}$. This method gave a yield of 11\% steviol glycosides: $7 \%$ stevioside and $4 \%$ rebaudioside $\mathrm{A}$. The extract was then passed through a 63- $4 \mathrm{~m}$ mesh to eliminate the remaining material, thus avoiding fouling of the filtration equipment.

Another popular extraction solvent for conventional extraction of Stevia glycosides is alcohol, specifically ethanol [15]. In it, an aliquot of $100 \mathrm{~g}$ of $S$. rebaudiana leaves were mixed with $1000 \mathrm{~mL}$ of ethanol and water, and extracted using a Soxhlet $(500 \mathrm{~mL})$ run for two cycles (approximately $100 \mathrm{~min}$ ). The extract was then concentrated until dryness at $70{ }^{\circ} \mathrm{C}$ in a rotary evaporator under vacuum and then lyophilized. Similarly, a quantity of $5 \mathrm{~kg}$ dry $S$. rebaudi ana leaves was treated and soaked in hexane to eliminate undesired pigments and other waxy material present on the surface of the Stevia leaves [28]. The dry leaves were then crushed to a fine powder. The retrieved leaf powder was then soaked in a $\mathrm{pH} 5$ aqueous solution at a ratio of 1:10 (leaf: water) and shaken for $2-3 \mathrm{~h}$ at $80{ }^{\circ} \mathrm{C}$. After shaking, the solution was extracted with pressurized hot water extraction (PHWE) for $10 \mathrm{~min}$ under the following conditions: $10 \mathrm{kPa}$ pressure, $120 \mathrm{rpm}$, temperature 100 $110^{\circ} \mathrm{C}$. This protocol could be considered as a pre-treatment for the clarification of the crude extract. Optimum extraction conditions were revealed as $211 \mathrm{bar}, 80^{\circ} \mathrm{C}$ and $17.4 \%$, which yielded $36.66 \mathrm{mg} \cdot \mathrm{g}^{-1}$ stevioside and $17.79{\mathrm{mg} \cdot \mathrm{g}^{-1}}^{-1}$ rebaudioside $\mathrm{A}$. The total glycoside composition was close to those obtained using conventional water extraction $\left(64.49 \mathrm{mg} \cdot \mathrm{g}^{-1}\right)$ and a little higher than ethanol extraction $\left(48.60 \mathrm{mg} \cdot \mathrm{g}^{-1}\right)$.

Also, Ion Exchange Extraction was tested [35]. The authors describe a method of extraction and clarification by selective absorption with $\mathrm{X}$ and A zeolites. They indicate the efficiency of barium and calcium ions in $\mathrm{NaX}$ and $\mathrm{NaA}$ zeolites during the ion exchange phase, and demonstrate that the use of the CaX zeolite during extraction improves clarification without producing alterations in the initial characteristics of concentration, glycosides and flavor. The results indicate that one may obtain in the first $2 \mathrm{~h}$ (according to the proposed conditions) a high clarification percentage, followed by a subsequent gradual decline. With a flow rate of $1.25 \mathrm{~mL} \cdot \mathrm{min}^{-1}$, clarification becomes approximately constant during $90 \%$ of the time with a clarification of between $55-60 \%$ in the whole process. Lastly, the authors highlight the possibility of zeolite reuse given that $65 \%$ to $70 \%$ clarification of the extract was achieved with regenerated $\mathrm{CaX}$ zeolite.

Conventional extraction assisted by ultrasound and microwave was tested for the same purpose [36]. In this study three types of conventional extraction were described: cold $\left(25^{\circ} \mathrm{C}\right)$ for $12 \mathrm{~h}$; extraction with ultrasound at $(35 \pm 5){ }^{\circ} \mathrm{C}$ for $30 \mathrm{~min}$; and microwave-assisted extraction (MAE), performed at different wattages (from $20 \mathrm{~W}$ to $160 \mathrm{~W}$ ) at time intervals of between $30 \mathrm{~s}$ and $5 \mathrm{~min}$ and at temperatures of between $10-90{ }^{\circ} \mathrm{C}$. Optimum MAE conditions were found to be $80 \mathrm{~W}$, for $1 \mathrm{~min}$ at $50{ }^{\circ} \mathrm{C}$. In this study, the MAE yielded $8.64 \%$ and $2.34 \%$ of stevioside and rebaudioside A, respectively, while conventional and ultrasound techniques yielded $6.54 \%$ and $1.20 \%$, and $4.20 \%$ and $1.98 \%$ of stevioside and rebaudioside A, respectively. The authors observed that the efficiency of extraction using PHWE (pressurized hot water extraction) or MAE was comparable or superior to that obtained by heat reflux extraction.

On the other hand, extraction by the supercritical fluid method has been selected and studied by several authors [15, 37]. In these studies, glycosides from Stevia leaves were obtained by supercritical fluid extraction, through a two-step process: firstly, extraction of $\mathrm{CO}_{2}$ at 200 bar and $30^{\circ} \mathrm{C}$, and, secondly, extraction of $\mathrm{CO}_{2}$ and water. The general extraction curves for the Stevia and $\mathrm{CO}_{2}$ system showed a typical form and were successfully described [37]. Other studies mention the Japanese patent that provides information about the supercritical fluid 
extraction method used to obtain Stevia glycosides with carbon dioxide and co-solvents such as methanol, ethanol and acetone [38]. In other studies, the authors produced a statistical design to evaluate the effect of different pressures (150-350 bar), temperatures $\left(40-80{ }^{\circ} \mathrm{C}\right)$ and the concentration $(0$ $20 \%$ ) of the ethanol-water mix (70:30) as the solvent, with a $\mathrm{CO}_{2}$ flow of $15 \mathrm{~g} \cdot \mathrm{min}^{-1}$ for $60 \mathrm{~min}$ [15]. The optimum extraction conditions, according to the results, were 211 bar, $80{ }^{\circ} \mathrm{C}$ and $17.4 \%$ of solvent, which gave $36.66 \mathrm{mg} \cdot \mathrm{g}^{-1}$ of stevioside and $17.79 \mathrm{mg} \cdot \mathrm{g}^{-1}$ of rebaudioside A. The composition of the extract was similar to that obtained using conventional extraction methods with water $\left(64.49 \mathrm{mg} \cdot \mathrm{g}^{-1}\right)$ and a little higher than that obtained with ethanol $\left(48.60 \mathrm{mg} \cdot \mathrm{g}^{-1}\right)$. The results also demonstrated that stevioside yield is not significantly improved by increasing the pressure above 300 bar.

Enzymatic extraction was also used successfully [25]. In this investigation, the authors studied different extraction parameters, notably duration, temperature, the enzymes used and the concentration of each one. The enzymes used for extraction were: pectinase, cellulase and hemicellulose. They were tested at five concentrations $(0.5 \%, 1 \%$, $2 \%, 3 \%$ and $4 \%, \mathrm{w} / \mathrm{v}$ ), under different temperature conditions as follows (35, 45 and 55$)^{\circ} \mathrm{C}$ for pectinase; $(40,50$ and 60$){ }^{\circ} \mathrm{C}$ for cellulase; and $(50,60 \text { and } 70)^{\circ} \mathrm{C}$ for hemicelullase, and over different time periods [(15, 30 and 45) min]. The results demonstrated the feasibility of enzymatic extraction, which, according to the authors, is more efficient than conventional methods using solvents. The treatment which gave the highest yield of stevioside was $1 \mathrm{~h}$ at $60{ }^{\circ} \mathrm{C}$, with hemicellulase.

Similarly, the effect of chitosan as a flocculating agent during the clarification of an aqueous extract of Stevia leaves was investigated [39]. Extraction was done at a leaf:water ratio of 1:10 (g:mL). The authors investigated the following conditions during the flocculation step: solution of acetic acid with $1 \%$ chitosan and dry Stevia leaves 2:1 (mL:g), $\mathrm{pH}$ 6, flocculation temperature $45^{\circ} \mathrm{C}$ and flocculation time $4 \mathrm{~h}$. A clarification rate of $86.63 \%$ was obtained with a loss of stevioside of only $6.89 \%$. The authors concluded that flocculation of the extract with chitosan represents an efficient alternative, with yields comparable to those obtained by separation methods with membranes. In addition, no special equipment is needed and the waste materials are easily biodegraded, thus respecting environmental safety issues.

Lastly, based on a large number of patents [40-42, among others] which are deepened extraction and purification processes, we propose a general scheme for obtaining a steviol glycoside extract powder from leaves of Stevia [based on 13, 43] (figure 2). In relation to the purification methods, amongst these, the membrane filtration technique is notable in that it manages to achieve adequate yields, without resorting to intense treatments, thus representing a 'green', environmentally friendly option. The most salient results obtained during applications of this particular technique were synthesized (table II).

\section{Uses and applications in the food industry}

From the above-mentioned considerations, it is clear that the addition of steviol glycosides can increase the palatability and enjoyment of food by improving flavors and smells [3]. Proof of this is the growing number of Stevia-based products on the world market, such as drinks, table-top sweeteners, candy and other processed foods, personal hygiene products and various Japanese delicacies.

Specifically, Stevia extracts have been used to sweeten low-calorie soft drinks, soy sauce, dried seafood, candy, ice cream, chewing gum and yogurt in several countries, but principally Japan, Korea and Brazil [28].

Information about the proportions of these sweeteners used in each type of product is available from the literature [48]. We listed some of the recommended values (table III)

There have been several investigations undertaken aimed at evaluating the potential of Stevia as a sweetener of specific products. For example, Lisak et al. prepared 


\section{González et al.}

Figure 2.

General scheme for the preparation of a purified mixture of steviol glycosides from Stevia leaves by the membrane filtration technique [based on 13, 43].

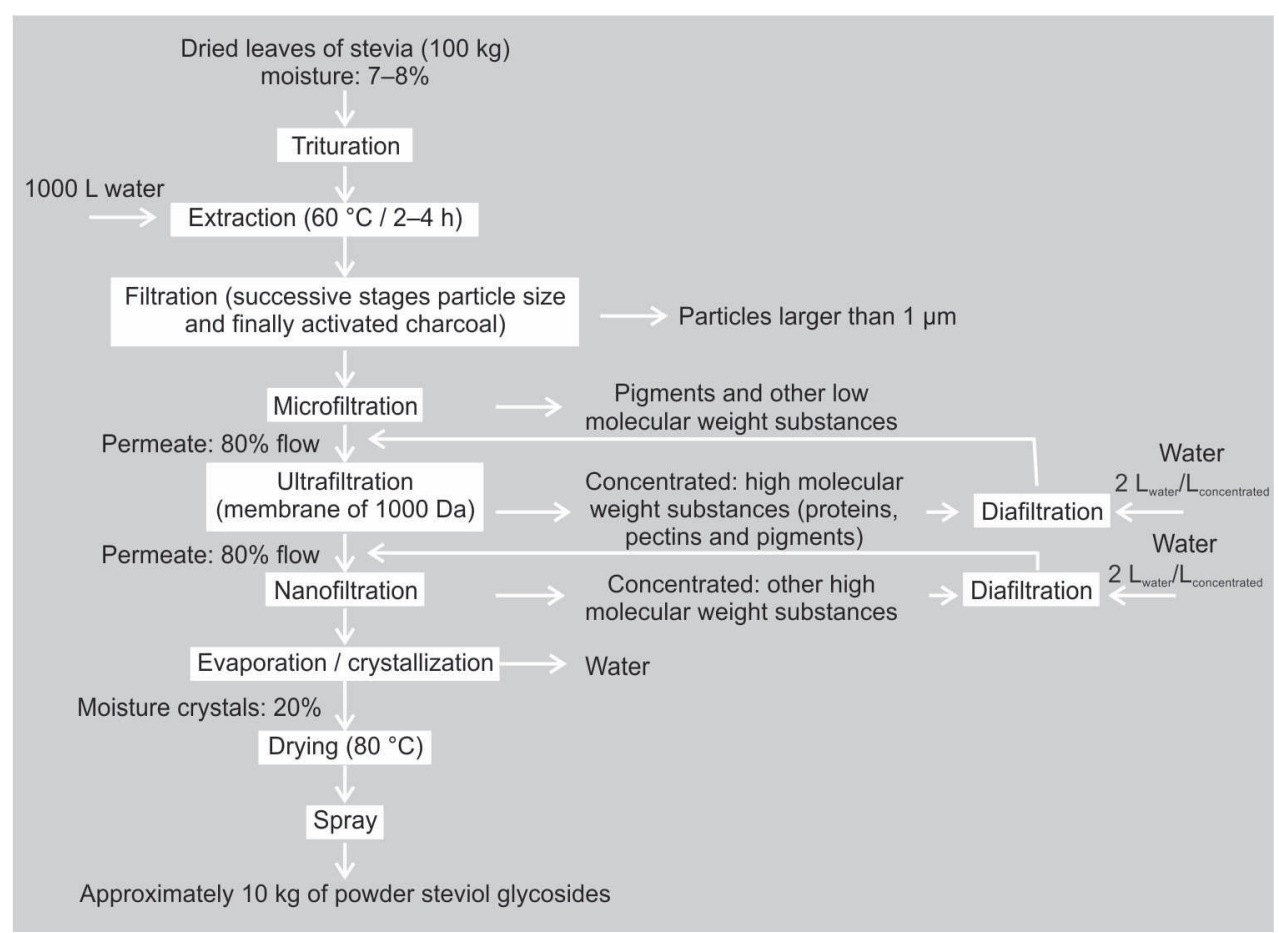

strawberry-flavored yogurt sweetened with either sucrose, Stevia or equal proportions of sucrose and Stevia, this last a pure extract with $90 \%$ stevioside content, at three different concentrations [49]. According to the results given by the sensory panel judges, the authors determined that $6 \mathrm{~g}$ of Stevia is equivalent to $1000 \mathrm{~g}$ of sucrose. In taste tests, the yogurt sweetened with $4.5 \mathrm{~g}$ $100 \mathrm{~g}^{-1}$ of equal parts of sucrose and Stevia obtained the highest sensory acceptance scores. The apparent viscosity of the finished products was not affected by the addition of Stevia. Furthermore, after 7 days of cold storage, the degree of sweetness of all the different formulations tested remained the same as that of fresh samples (made the day before) of products prepared with sucrose.

Another study evaluating Stevia-sweetened yogurt was carried out by Guggisberg et al. [50]. Yogurt made with 8\% sugar was replaced by Stevia, and combinations of Stevia with other sweeteners. Neither Stevia nor the other two commercial sweeteners used had any negative effects on the yogurtmaking process or the $\mathrm{pH}$, and did not significantly change the fermentation time or the generation of the casein network. However, the yogurt made with Stevia only had an unpleasant taste and thus could not be recommended [50].

Nevertheless, the yogurt made with a combination of Actilight (a commercial mixture of short-chain fructo-oligosaccharides) and Stevia showed a similar profile to the variant containing $8 \%$ sucrose. The authors concluded that low-calorie yogurts could be manufactured using commercial sweeteners including Stevia without modifying standard technological procedures.

A similar study, but this time applied to cake, assessed the rheological and microstructural properties and the final quality of cakes made by replacing sugar with stevioside (sweetener containing 80\% stevioside) and liquid sorbitol [51]. The addition of hydrocolloids, emulsifiers and debittered fenugreek seed powder was also considered. The results showed that the addition of stevioside did not change the amylographic viscosity of wheat flour batter during heating and cooling, unlike sucrose, which increases this property. The authors concluded that it is possible to replace sugar with stevioside using this cake recipe while 


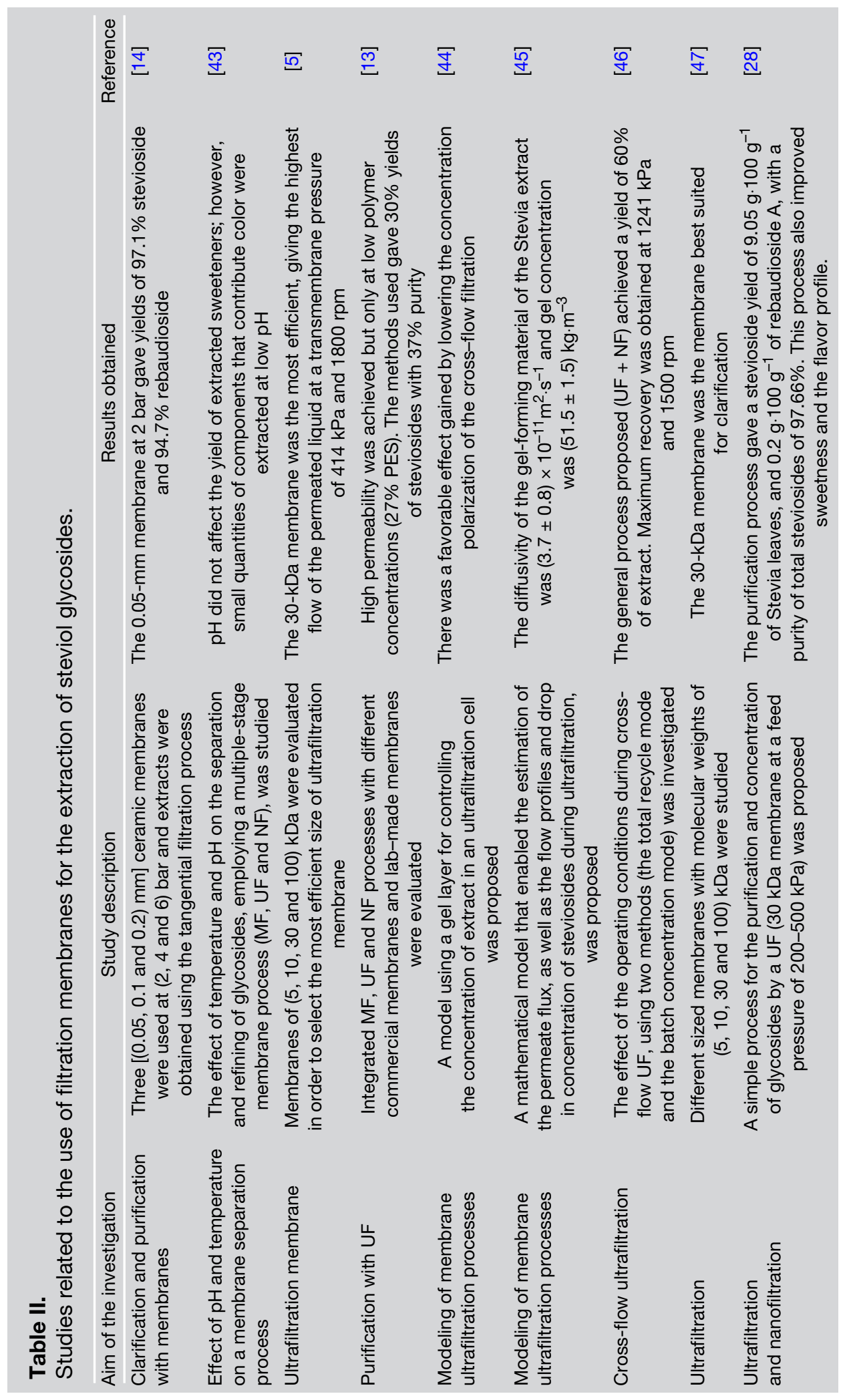


Table III.

Concentrations of rebaudioside $A$ in various products [1].

$\begin{array}{lc}\text { Product } & \begin{array}{c}\text { Range } \\ \left(\mathrm{mg} \cdot \mathrm{kg}^{-1} \text { or } \mathrm{mg} \cdot \mathrm{L}^{-1}\right)\end{array} \\ \text { Carbonated soft drinks } & 50-600 \\ \text { Still beverages } & 50-600 \\ \text { Powdered soft drinks } & 200-200 \\ \text { Chewing gum } & 300-6000 \\ \text { Dairy products } & 150-1000 \\ \text { Edible gels } & 200-1000 \\ \text { Nutraceuticals } & 200-1000 \\ \text { Pharmaceuticals } & 50-1000\end{array}$

maintaining the rheological properties of the final product.

Another study investigated the physical properties of cocoa powder drinks prepared with different fat contents and different sweeteners including Stevia extract [52]. The authors evaluated the bioactive content (content of polyphenols and antioxidant capacity) and the sensory properties of prepared cocoa drinks. The results showed that the type of sweetener used did not affect the polyphenolic constituents of the cocoa mixtures prepared. The results of the sensory analysis revealed a preference for cocoa drinks made with the sweeteners (aspartame/acesulfame K and Stevia extract) and a significant difference in the sensory attributes between the experimental mixtures and the control.

Finally, Mogran and Dashora determined the amount of Stevia extract (obtained by boiling Stevia leaf powder in water) and other commercial sweeteners required to produce a degree of sweetness equivalent to sugar [53]. Once the amounts required to achieve the desired sweetness had been determined, eleven products were elaborated: milk, coffee, tea, gajar halwa, milkshake, kheer, curd, lemon water, custard, halwa and lapsi, replacing the sugar in the recipes with either Stevia extract or one of the other commercial sweeteners. The results revealed that $1.5 \mathrm{~mL}$ of Stevia extract in $100 \mathrm{~mL}$ of liquid was equivalent to $5 \mathrm{~g}$ of sugar. The recipes prepared using Stevia were more acceptable than the other sweet- eners tested, as indicated by the fact that they were given the highest sensory acceptance scores by members of the panel (7.677.90), thus occupying first place ahead of the artificial sweeteners tested. They were also statistically comparable in taste to sugar (sugar scores: $7.47-8.47)(p>0.001 \%)$ in the case of coffee, halwa, milk drinks, kheer and lapsi, and were scored as tastier for the rest of the products evaluated.

All of the above indicate the huge potential of Stevia as a realistic alternative to sugar in the products investigated. Not least because in addition to delivering similar physical and sensory properties, it also provides beneficial health effects for consumers.

\section{Formulation of fruit juice sweetened with Stevia}

A considerable number of studies have examined the use of sweeteners containing Stevia in the manufacture of fruit juices. One of these, carried out by Sharoba et al., determined the rheological properties of two nectars, the first based on papaya and the second on apricot [4]. Both nectars were sweetened with aspartame and stevioside, to which various food hydrocolloids (guar gum, xanthan gum and arabic gum) were added. The liquids were characterized as being pseudoplastic with elastic limits at different temperatures $\left[(5,25,50 \text { and } 75)^{\circ} \mathrm{C}\right]$. Both sweeteners, however, lowered the 
pseudoplasticity, thus producing a decrease in the consistency index, plastic viscosity (or the resistance of fluid to flow) and shear stress.

As regards the sensory evaluation, all samples of both nectars, including the control, obtained medium/high scores. It should be noted that both the apricot and the papaya nectars which contained only the sweeteners (without the addition of any of the hydrocolloids) were given the lowest scores compared with the rest of the samples.

Another study assessed the sensory properties of peach nectar made with sucrose and other sweeteners (aspartame, cyclamate:saccharin mix 2:1, Stevia, sucralose and acesulfame-K) by means of a quantitative descriptive analysis [2]. Once the ideal concentration of each sweetener, that is, the concentration of the sweetener equivalent to sucrose sweetness, was determined, the sensory attributes of each sample were evaluated. The results show that the different formulations were not statistically different $(P \leq 0.05)$ as regards yellow coloring, cloudy appearance and brightness. In spite of this, peach nectar sweetened with Stevia received the highest scores for the following negative attributes: grass aroma, bitterness, residual bitterness and residual sweetness; aspects which significantly influenced its acceptance in consumer tests. In terms of acidity, astringency, visual viscosity and body, however, no differences $(P \leq 0.05)$ among samples were found. Thus, Stevia-sweetened nectar showed similar characteristics to nectars sweetened with sucrose.

A similar investigation sensorially evaluated industrialized pineapple juice, sweetened with sucralose, aspartame, Stevia (pure commercial extract), cyclamate/saccharin and sucrose [54]. The flavor profile obtained showed that juice made with Stevia had a sour and bitter aftertaste, demonstrating that Stevia may not be the appropriate sweetener for this particular juice formulation. In addition, residual sweetness, sweet flavor, spiciness and metallic taste were cited for these samples, but by very few tasters.

These same sweeteners were also studied in guava juice $[55,56]$. As regards sweetness, guava juice sweetened with sucrose or aspartame achieved similar acceptance ratings $(81 \%)$, while samples sweetened with Stevia (extract obtained from leaves) and cyclamate/saccharine were given higher scores for negative attributes, positioning them in the rejection zone as per the hedonic scale used: "I have a moderate dislike to these drinks" and "I don't like these drinks very much". The authors indicate that the matrix (guava nectar) did not affect the perception of sweetness of any of the sweeteners. Similar results were reported by Cavallini and Bolini, who compared the temporal perception of sweetness, bitterness and flavor in reconstituted mango juice sweetened with sucrose, cyclamate:saccharin 2:1, aspartame, sucralose and Stevia [57]. These authors concluded that, of all the sweeteners, aspartame showed a temporal profile closest to that of sucrose for the majority of the parameters tested. The juice made with Stevia, however, was the least similar to sucrose.

From these studies, it can be seen that many products sweetened with Stevia extract tend to have a bitter residual taste [55-57]. This may be attributed to the high proportions of stevioside glycoside contained in the mixture of leaf components obtained during the extraction process. This negative element is eliminated when plant varieties with higher concentrations of rebaudioside A are used, or simply by using steviol glycosides in pure form, due to their superior flavor profile [6]. Finally, it is important to highlight that sensory responses to formulated products are directly influenced by the food matrix used. Thus, each particular fruit juice sweetened with Stevia should be evaluated in depth in order to determine whether or not the aforementioned unpleasant residual taste can be perceived.

\section{Conclusions and future outlook}

Judging by the published literature, the use of steviol glycosides as sweeteners is an area that requires much further research, due to both their high appeal and commercial 
potential. This is very important, not only for manufacturers of industrial fruit juices, but also in general for various food applications. In this context, much research is still needed, not only to develop and optimize steviol glycoside extraction, but also to improve the taste of products sweetened with these compounds. Thus, the continued evaluation of these ingredients as regards aspects such as the intensity, persistence of sweet taste and absence of other residual flavors is necessary in order to meet the demands of today's consumers and ensure their acceptance, preference and choice by the general public

Stevia-sweetened juices that have been evaluated so far (pineapple, peach, guava, apricot and papaya) presented the aforementioned unpleasant aftertaste. It is therefore necessary to investigate the most effective treatment to prevent its presence, especially in the case of citrus fruit juices that demand a greater proportion of sweetener. It should be tested with other fruits that naturally contain antioxidants that prevent the oxidation that causes the aforementioned aftertaste.

On the other hand, according to the authors, the addition of Stevia leaves in fruit juice extraction and clarification should also be considered in order to evaluate possible interactions between the food matrix (juice) and components responsible for the aftertaste.

Furthermore, and given that there is currently a sizeable and growing market for the commercialization of Stevia-containing products, the above-mentioned optimization of production and processing should be undertaken concurrently in order to avoid limitations in the supply of steviol glycosides, an aspect that could restrict their extensive use in the demanding future that lies ahead.

Finally, the patterns of use of Stevia and its approval by the major international regulatory organizations, who have confirmed both the safety of this product for human consumption and its stability over time, point towards its development as an ubiquitous sugar alternative. It is expected that steviol glycosides will be used mainly in the manufacture of beverages, along with other traditional foods (such as dairy products, bread and cakes, confectionery, etc.), table-top sweeteners, functional food and beverages, and nutritional supplements, in addition to their use in personal care products (such as toothpaste) and as an active pharmaceutical ingredient or excipient.

\section{References}

[1] Priya K., Gupta V.R., Srikanth K., Natural sweeteners: A complete review, J. Pharm. Res. 4 (2011) 2034-2039.

[2] Porto J.M., Bolini H.M., Descriptive profile of peach nectar sweetened with sucrose and different sweeteners, J. Sens. Stud. 23 (2008) 804-816.

[3] Puri M., Sharma D., Tiwari A.K., Downstream processing of stevioside and its potential applications, Biotechnol. Adv. 29 (2011) 781-791.

[4] Sharoba A.M., El-Desouky A.I., Mahmoud M.H., Effect of addition some hydrocolloids and sweeteners on flow behavior and sensory properties of papaya-apricot nectar blends, J. Food Process. Technol. 3 (2012) 3-8.

[5] Chhaya R., Mondal S., Majumdar G.C., Sirshendu D.E., Clarifications of stevia extract using cross flow ultrafiltration and concentration by nanofiltration, Sep. Purif. Technol. 89 (2012) 125-134.

[6] Dacome A.S., Da Silva C.C., Da Costa C.E., Sweet diterpenic glycosides balance of a new cultivar of Stevia rebaudiana Bertoni: Isolation and quantitative distribution by chromatographic, spectroscopic, and electrophoretic methods, Process. Biochem. 40 (2005) 3587-3594.

[7] Ohta M., Sasa S., Inoue A., Tamai I., Fujita I., Morita K., Matsuura F., Characterization of novel steviol glycosides from leaves of Stevia rebaudiana Morita, J. Appl. Glycosci. 57 (2010) 199-209.

[8] Wölwer U., The leaves of Stevia rebaudiana (Bertoni), their constituents and the analyses thereof: a review, J. Agric. Food Chem. 60 (2012) 886-895.

[9] Geuns J.M., Buyse J., Vankeirsbilk A., Temme E., Metabolism of stevioside by 
healthy subjects, Exp. Biol. Med. 232 (2006) 164-173.

[10] Huxtable R.J., Pharmacology and toxicology of stevioside, rebaudioside $A$, and steviol. Stevia: the genus Stevia, Taylor and Francis, London, U.K. / New York, U.S.A., 2002, 160177.

[11] Prakash I., Dubois G.E., Clos J.F., Wilkens K.L., Fosdick L.E., Development of rebiana, a natural, non-caloric sweetener, Food Chem. Toxicol. 46 (2008) Suppl. 7 S75-82.

[12] Chaturvedula V.S., Prakash I., A new diterpene glycoside from Stevia rebaudiana, Molecules 16 (2011) 2937-2943.

[13] Vanneste J., Sotto A., Courtin C., Application of tailor-made membranes in a multi-stage process for the purification of sweeteners from Stevia rebaudiana, J. Food Eng. 103 (2011) 285-293.

[14] Reis M.H., Da Silva F.V., Andrade C.M., Clarification and purification of aqueous Stevia extract using membrane separation process, J. Food Eng. 32 (2009) 338-354.

[15] Erkucuk A., Akgun I.H., Yesil-Celiktas O., Supercritical $\mathrm{CO}_{2}$ extraction of glycosides from Stevia rebaudiana leaves: Identification and optimization, J. Supercrit. Fluid. 51 (2009) 29-35.

[16] Ateh J.O., Onagbesan O.M., Tona K., Decuypere E., Geuns J.M., Buyse J., Evaluation of supplementary stevia (Stevia rebaudiana, Bertoni) leaves and stevioside in boiler diets: effect on feed intake, nutrient metabolism blood parameters and growth performance, J. Anim. Physiol. Anim. Nutr. 92 (2008) 640-649.

[17] Maki K.C., Curry L.L., Reeves M.S., Toth P.D., Mckenney J.M., Farmer M.V., Schwartz S.L., Lubin B.C., Boileau A.C., Dicklin M.R., Carakostas M.C., Tarka S.M.. Chronic consumption of rebaudioside $A$, a steviol glycoside, in men and women with type 2 diabetes mellitus, Food Chem. Toxicol. 46 (2008) 47-53.

[18] Wingard E.R., Brown J.P., Enderlin F.E., Dale J.A., Hale R.L., Seitz C.T., Intestinal degradation and absorption of the glycosidic sweeteners stevioside and rebaudioside $A$, Cell. Mol. life Sci. 36 (1980) 519-520.

[19] Toyoda K., Matsui H., Shoda T., Uneyama C., Takada K., Takahashi M., Assesment of the carcinogenicity of stevioside in F344 rats, Food Chem. Toxicol. 35 (1997) 597-603.

[20] Kochikyan V.T., Markosyan A.A., Abelyan L.A., Balayan A.M., Abelyan V.A., Combined enzymatic modification of stevioside and rebaudioside A, Appl. Biochem. Microbiol. 42 (2006) 31-37.

[21] Gregersen S., Jeppesen P.B., Holst J.J., Hermansen K., Antihyperglycemic effects of stevioside in type 2 diabetic subjects, Metabolism 53 (2004) 73-76.

[22] Feri L.A., Alves W., Yamada S.S., Gazola S., Batista M.R., Bazotte R.B., Investigation of antihypertensive effect of oral crude stevioside in patients with mild essential hypertension, Phytother. Res. 20 (2006) 732-736.

[23] Hsieh M.H., Chan P., Sue Y.M., Liu J.C., Liang T.H., Huang T.Y., Tomlinson B., Chow M.S., Kao P.F., Chen Y.J., Efficacy and tolerability of oral stevioside in plants with mild essential hypertension: A two year, randomized, placebo controlled study, Clin. Ther. 25 (2003) 2797-2808.

[24] Chatsudthipong V., Muanprasat C., Stevioside and related compounds: Therapeutic benefits beyond sweetness, Pharm. Ther. 121 (2009) 41-54.

[25] Puri M., Sharma D., Barrow C., Optimisation of novel method for the extraction of steviosides from Stevia rebaudiana leaves, Food Chem. 132 (2012) 1113-1120.

[26] Brusick D., A critical review of the genetic toxicity of steviol and steviol glycosides, Food Chem. Toxicol. 46 (2008) S85-S90.

[27] Chatsudthipong V., Muanprasat C., Stevioside and related compounds; therapeutic benefits beyond sweetness, Pharmacol. Ther. 121 (2009) 41-54.

[28] Carakostas M., Curry L., Boileau A., Brusick D., Overview: The history, technical function and safety of rebaudioside $A$, a naturally occurring steviol glycoside, for use in food and beverages, Food Chem. Toxicol. 46 (2008) S5-S9.

[29] Kroyer G., The low calorie sweetener stevioside: Stability and interaction with food ingredients, Lebensm. Wiss. Technol. 32 (1999) 509-512.

[30] Abou-Arab A.E., Abou-Arab A.A., Abu-Salem M.F., Physico-chemical assessment of natural sweeteners steviosides produced from Stevia rebaudiana Bertoni plant, Afr. J. Food Sci. 4 (2010) 269-281.

[31] Jooken E., Amery R., Struyf T., Duquenne B., Geuns J., Meesschaert B., Stability of steviol glycosides in several food matrices, J. Agric. Food Chem. 42 (2012) 10606-10612. 
[32] Woelwer U., Tomberg W., Wawrzun A., Investigations on the stability of stevioside and rebaudioside A in soft drinks, J. Agric. Food Chem. 58 (2010) 12216-12220.

[33] Gardana C., Simonetti P., Canzi E., Zanchi R., Pietta P.G., Metabolism of stevioside and rebaudioside A from Stevia rebaudiana extracts by human microflora, J. Agric. Food Chem. 51 (2003) 6618-6622.

[34] Prakash I., Clos J., Chaturvedula V., Stability of rebaudioside $A$ under acidic conditions and its degradation products, Food Res. Int. 48 (2012) 65-75.

[35] Moraes E., Machado N., Clarification of Stevia rebaudiana (Bert.) extract by adsorption in modified zeolites, Acta Scientiarum 23 (2001) 1375-1380.

[36] Jaitak V., Bandna B. S., Kaul V. K., An efficient microwave-assisted extraction process of stevioside and rebaudioside-A from Stevia rebaudiana (Bertoni), Phytochem. Anal. 20 (2009) 240-245.

[37] Yoda S., Marques M., Petenate A., Meireles M., Supercritical fluid extraction from Stevia rebaudiana Bertoni using $\mathrm{CO}_{2}$ and $\mathrm{CO}_{2}+$ water: extraction kinetics and identification of extracted components, J. Food Eng. 57 (2003) 125-134.

[38] Tan S., Shibuta Y., Tanaka O., Isolation of sweetener from Stevia rebaudiana, Jpn. Kokai, Patent No. 63177 764, 1983.

[39] Xie J., Wang P., Su W., Application of chitosan flocculation method in clarification of water extract from Stevia rebaudiana Berton leaves and flocculation mechanism analysis, Food Sci. 32 (2012) 1-6.

[40] Abelyan V.H., Ghochikyan V.T., Markosyan A., Adamyan M.O., Abelyan L.A., Extraction, separation and modification of sweet glycosides from the Stevia rebaudiana plant, Patent No. US 7838044 B2, 2010.

[41] Markosyan A., Purkayastha S., Malsagov M., Process for manufacturing a sweetener and use thereof, Patent No. US 2011/0 195169 A1, 2011.

[42] Abelyan V.H., Markosyan A., Abelyan L.A., High-purity rebaudioside D, Patent No. US 2011/0 092684 A1, 2011.

[43] Zhang S., Kumar S., Kutowy O., Membranebased separation scheme for processing weeteners from Stevia leaves, Food Res. Int 33 (2000) 617-620.
[44] Mondal S., Chhaya R., De S., Prediction of ultrafiltration performance during clarification of stevia extract, J. Membr. Sci. 396 (2012) 138-148.

[45] Mondal S., Chhaya R., De S., Modeling of cross flow ultrafiltration of Stevia extract in a rectangular cell, J. Food Eng. 112 (2012) 326-337.

[46] Chhaya R., Mondal S., Majumdar G.C., De S., Clarifications of Stevia extract using cross flow ultrafiltration and concentration by nanofiltration, Separation Purif. Technol. 89 (2012) 125-134.

[47] Mondal S., Rai C., De S., Identification of fouling mechanism during ultrafiltration of Stevia extract, Food Bioprocess Technol. (2011) 1-10.

[48] Kinghorn A.D., Soejarto D.D., Kennelly E.J., Kim D.S., Ohtani K., Yamasaki K., The genus Stevia, Med. Arom. Plants-Ind. Profiles 19 (2002) 52-64.

[49] Lisak K., Jeličić I., Tratnik L., Božanić R., Sensory evaluation of the strawberry flavored yoghurt with stevia and sucrose addition, Croat. J. Food Technol. Biotechnol. Nutr. 7 (2012) 39-43.

[50] Guggisberg D., Piccinali P., Schreier K., Effects of sugar substitution with Stevia, Actilight and Stevia combinations or Palatinose on rheological and sensory characteristics of low-fat and whole milk set yogurt, Int. Dairy J. 21 (2011) 636-644.

[51] Manisha G., Soumya C., Indrani D., Studies on interaction between stevioside, liquid sorbitol, hydrocolloids and emulsifiers for replacement of sugar in cakes, Food Hydrocoll. 29 (2012) 363-373.

[52] Belscak A., Bonkovic M., Komes D., Bauman I., Horzic D., Dujmic F., Matijasec M., Physical properties and bioactive constituents of powdered mixtures and drinks prepared with cocoa and various sweeteners, J. Agric. Food Chem. 58 (2010) 7187-7195.

[53] Mogran R., Dashora V., Exploring the use of Stevia rebaudiana as a sweetener in comparison with other sweeteners, J. Hum. Ecol. 25 (2009) 117-120.

[54] Marcellini P.S., Deliza R., Bolini H.M., Caracterização sensorial de suco de abacaxi concentrado, reconstituído e adoçado com diferentes edulcorantes e sacarose, Alim. Nutr. 17 (2006) 143-150.

[55] Fernandes A.G., Machado P.H., Maia G., Silva D.S., Santos S.M., Sensory evaluation of guava drinks sweetened with different 
sweetening agents, Ciênc. Tecnol. Aliment. 29 (2009) 358-364.

[56] Koguishi C.A., Alves V.H., Bolini H.M., Equisweetness and sweetening power of guava nectars sweetned with different sweetening agents, Rev. Bras. Tecnol. Agroind. 2 (2008) 26-36.
[57] Cavallini C.U., Bolini H.M., Comparação da percepção temporal de doçura, amargor e sabor de fruta em suco de manga reconstituído e adoçado com sacarose, mistura ciclamato/sacarina 2:1, aspartame, sucralose e estévia, Bol. CEPPA 23 (2005) 361382.

\section{Resumen de las principales propiedades de los esteviol glucósidos y su interés en la industria alimentaria.}

Resumen - Introducción. En las últimas décadas, se ha incrementado el interés por desarrollar edulcorantes naturales, no calóricos, saludables y similares a la sacarosa. Una de las alternativas más prometedoras la constituye los esteviol glucósidos, compuestos de gran dulzor extraídos de las hojas de Stevia rebaudiana Bertoni. En esta revisión, se describen las particularidades de la mencionada planta. Características y propiedades. Se puntualizan los principales Steviol glucósidos reportados en la bibliografía, así como sus principales características y propiedades. Toxicidad y legislación. Se expone el panorama actual sobre la toxicidad y el marco legal de los mencionados endulzantes. Técnicas de extracción. Se describen las técnicas desarrolladas para su extracción y purificación; entre ellas, la extracción convencional con agua/solventes, intercambio iónico, extracción enzimática, por fluido supercrítico y con especial atención a la filtración por membranas; por sus ventajas comprobadas en la purificación del extracto acuoso obtenido por lixiviación de las hojas. Aplicaciones. Se presentan diversas evidencias relacionadas con la aplicación de esteviol glucósidos en la industria de alimentos, haciendo énfasis en su utilización para la formulación de jugos de frutas. Conclusiones. Se proyectan, según los juicios de los autores, las perspectivas futuras de estos edulcorantes. Se destaca la necesidad de investigación en el área, por su gran atractivo y potencial comercial, la cual debe estar enfocada en la evaluación continuada en lo que respecta a la intensidad, persistencia de sabor dulce y la ausencia de otros sabores residuales, con el fin de asegurar su aceptación, preferencia y elección por parte del público en general.

Stevia rebaudiana / hojas / extracción / glicosidos / edulcorantes / steviosido / industria alimentaria / jugo de frutas 